\title{
Factors affecting variation of different measures of cheese yield and milk nutrient recovery from an individual model cheese-manufacturing process
}

\author{
C. Cipolat-Gotet, A. Cecchinato, ${ }^{1}$ M. De Marchi, and G. Bittante \\ Department of Agronomy, Food, Natural Resources, Animals and Environment (DAFNAE) University of Padova, viale dell'Università 16, \\ 35020 Legnaro (PD), Italy
}

\begin{abstract}
Cheese yield (CY) is the most important technological trait of milk, because cheese-making uses a very high proportion of the milk produced worldwide. Few studies have been carried out at the level of individual milk-producing animals due to a scarcity of appropriate procedures for model-cheese production, the complexity of cheese-making, and the frequent use of the fat and protein (or casein) contents of milk as a proxy for cheese yield. Here, we report a high-throughput cheese manufacturing process that mimics all phases of cheesemaking, uses 1.5-L samples of milk from individual animals, and allows the simultaneous processing of 15 samples per run. Milk samples were heated $\left(35^{\circ} \mathrm{C}\right.$ for 40 $\mathrm{min})$, inoculated with starter culture (90 min), mixed with rennet (51.2 international milk-clotting units/L of milk), and recorded for gelation time. Curds were cut twice (10 and 15 min after gelation), separated from the whey, drained (for $30 \mathrm{~min}$ ), pressed (3 times, 20 min each, with the wheel turned each time), salted in brine (for $60 \mathrm{~min}$ ), weighed, and sampled. Whey was collected, weighed, and sampled. Milk, curd, and whey samples were analyzed for $\mathrm{pH}$, total solids, fat content, and protein content, and energy content was estimated. Three measures of percentage cheese yield $(\% \mathrm{CY})$ were calculated: $\% \mathrm{CY}_{\mathrm{CURD}}, \% \mathrm{CY}_{\mathrm{SOLIDS}}$, and $\% \mathrm{CY}_{\text {WATER }}$, representing the ratios between the weight of fresh curd, the total solids of the curd, and the water content of the curd, respectively, and the weight of the milk processed. In addition, 3 measures of daily cheese yield ( $\mathrm{dCY}, \mathrm{kg} / \mathrm{d}$ ) were defined, considering the daily milk yield. Three measures of nutrient recovery (REC) were computed: $\mathrm{REC}_{\mathrm{FAT}}, \mathrm{REC}_{\mathrm{PROTEIN}}$, and $\mathrm{REC}_{\text {SOLIDS }}$, which represented the ratio between the weights of the fat, protein, and total solids in the curd, respectively, and the corresponding components in the milk. Energy recovery, $\mathrm{REC}_{\mathrm{ENERGY}}$, represented the energy content of the cheese compared with that in the milk. This
\end{abstract}

Received December 21, 2012.

Accepted July 29, 2013.

${ }^{1}$ Corresponding author: alessio.cecchinato@unipd.it procedure was used to process individual milk samples obtained from 1,167 Brown Swiss cows reared in 85 herds of the province of Trento (Italy). The assessed traits exhibited almost normal distributions, with the exception of $\mathrm{REC}_{\mathrm{FAT}}$. The average values $( \pm \mathrm{SD})$ were as follows: $\% \mathrm{CY}_{\mathrm{CURD}}=14.97 \pm 1.86, \% \mathrm{CY}_{\text {SOLIDS }}=7.18$ $\pm 0.92, \% \mathrm{CY}_{\mathrm{WATER}}=7.77 \pm 1.27, \mathrm{dCY}_{\mathrm{CURD}}=3.63$ $\pm 1.17, \mathrm{dCY}_{\text {SOLIDS }}=1.74 \pm 0.57, \mathrm{dCY}_{\text {WATER }}=1.88$ $\pm 0.63, \mathrm{REC}_{\mathrm{FAT}}=89.79 \pm 3.55, \mathrm{REC}_{\mathrm{PROTEIN}}=78.08$ $\pm 2.43, \mathrm{REC}_{\mathrm{SOLIDS}}=51.88 \pm 3.52$, and $\mathrm{REC}_{\mathrm{ENERGY}}$ $=67.19 \pm 3.29$. All traits were highly influenced by herd-test-date and days in milk of the cow, moderately influenced by parity, and weakly influenced by the utilized vat. Both $\% \mathrm{CY}_{\mathrm{CURD}}$ and $\mathrm{dCY}_{\mathrm{CURD}}$ depended not only on the fat and protein (casein) contents of the milk, but also on their proportions retained in the curd; the water trapped in curd presented an higher variability than that of $\% \mathrm{CY}_{\text {SOLIDS }}$. All REC traits were variable and affected by days in milk and parity of the cows. The described model cheese-making procedure and the results obtained provided new insight into the phenotypic variation of cheese yield and recovery traits at the individual level.

Key words: individual cheese yield, cheese-making, whey loss, fat and protein recovery

\section{INTRODUCTION}

Cheese yield per unit of milk processed, usually expressed as percentage cheese yield $(\mathbf{\%} \mathbf{C Y})$, is a key factor in the economics and profitability of dairy industries. Cheese yield, the recovery of individual milk constituents in the curd, and their loss in the whey all define the efficiency of the cheese-making process (Banks, 2007). These indices are influenced by 2 main aspects of milk quality: (1) animal-specific concerns, such as species (Othmane et al., 2002; Zicarelli et al., 2007), breed (Malacarne et al., 2006; De Marchi et al., 2008; Martin et al., 2009), stage of lactation (Wedholm et al., 2006), parity (Wedholm et al., 2006), feeding (Banks et al., 1986), and health (Politis and Ng-KwaiHang, 1988); and (2) cheese-making conditions, such as the handling and storage of the milk before being 
processed and the technologies adopted (Lucey and Kelly, 1994).

In general, experimental cheese-making trials are expensive and time consuming, and only allow for a small number of replicates. In the past $30 \mathrm{yr}$, many studies (Hicks et al., 1981; Hurtaud et al., 1995; Cologna et al., 2009) have described the production of model cheeses through laboratory cheese-making processes that allow $\mathrm{CY}$ to be assessed from samples ranging from 1 $\mathrm{mL}$ to more than $10 \mathrm{~L}$ per sample. Compared with trials carried out in cheese-making plants, these laboratory procedures offer the following benefits: the use of small quantities of milk; reduced time and cost for experiments; more possible treatments or replications per day; and the ability to estimate $\% \mathrm{CY}$ from individual animals.

It is generally agreed that individual \%CY is important for studies intended to test the existence of a genetic basis for these traits (Othmane et al., 2002) because daily $\mathrm{CY}$, expressed in kilograms of cheese produced (dCY), is the ultimate production objective of most dairy farmers. However, most of the studies that involve micro cheese-making procedures have used bulk milk, largely because it is very labor intensive to produce a high number of model cheeses from individual milk samples. Numerous steps are involved: individual milk sampling; milk analysis; milk weighing and heating; starter culture preparation and inoculation; $\mathrm{pH}$ measurement; rennet preparation and addition; gelation-time recording and curd cutting; whey drainage, sampling, and weighing; curd sampling and analysis; wheel formation, compression, salting, and weighing; and model-cheese ripening, weighing, and analysis.

Two previous studies (Hurtaud et al., 1995; Wedholm et al., 2006) estimated \%CY from individual cows using a micro cheese-making procedure; however, these studies examined only 6 and 45 animals, respectively. Therefore, the aims of the present study were (1) to develop a model cheese-manufacturing process that supports the measurement of $\% \mathrm{CY}$ at the individual level; (2) to characterize milk nutrient and energy recoveries in curd and whey losses at the individual level; (3) to estimate the daily production of cheese (dCY) of individual cows; and (4) to investigate several sources of variation for \%CY, dCY, and nutrient and energy recoveries in the curd, using milk from individual cows.

\section{MATERIALS AND METHODS}

\section{Animals and Milk Sampling}

Individual milk samples were obtained from a total of 1,167 Brown Swiss cows during the evening milking. Cows (2 subsamples per cow) were sampled from
85 herds (a maximum of 15 cows per herd) located in Trento province (Italy). The sampled cows represented different stages of lactation (25-388 DIM) and parities $(1-5)$. The present study is part of the Cowability-Cowplus projects. The sampling procedure was described in detail by Cipolat-Gotet et al. (2012) and Cecchinato et al. (2013). Collection, refrigeration, transport, and storage of milk samples were standardized to minimize differences among herds and collection dates. After collection, milk samples (without preservative) were immediately refrigerated at $4^{\circ} \mathrm{C}$. One subsample $(50$ $\mathrm{mL}$; designated for milk composition analysis) was transported to the Milk Quality Laboratory of the Trento Breeders Association (Trento, Italy). The second subsample (about 2,000 $\mathrm{mL}$; designated for cheese making) was transferred to the Milk Laboratory of the Department of Agronomy, Food, Natural Resources, Animals and Environment (DAFNAE) of the University of Padova (Legnaro, Padova, Italy). All samples were analyzed and processed on the following morning, within $20 \mathrm{~h}$ of collection. Information about cows and herds was obtained from the Superbrown Consortium of Trento (Trento, Italy).

Individual milk samples were analyzed for fat, protein, and casein percentages using a MilkoScan FT6000 (Foss, Hillerød, Denmark). Somatic cell count values were obtained from the Fossomatic FC counter (Foss) and were then converted to SCS by means of logarithm transformation (Ali and Shook, 1980). The milk pH values were obtained after the heating step of the cheese-making process, using a Crison Basic 25 electrode (Crison, Barcelona, Spain).

\section{Micro Cheese-Making Procedure}

The laboratory micro-manufacturing procedure for assessing \% CY proposed by Cologna et al. (2009), which showed good repeatability and reproducibility, was modified for a larger quantity of milk per sample $(1,500 \mathrm{~mL})$. The cheese-making facility consisted of 3 water baths with supplementary temperature controllers and pumps for water mixing. Each water bath contained 5 stainless steel micro-vats (micro-vat capacity: 1,500-mL). Thus, a single cheese-making session allowed analysis of up to 15 ( 3 water baths $\times 5$ vats) individual milk samples. Each milk sample $(1,500 \mathrm{~mL})$ was subjected to the procedure summarized in Figure 1.

Briefly, raw milk was heated to $35^{\circ} \mathrm{C}$, the $\mathrm{pH}$ was recorded, and the sample was inoculated with starter culture, which consisted of a freeze-dried formulation of thermophilic lactic bacteria (Delvo-Tec TS-10A DSL; DSM Food Specialties, Delft, the Netherlands) that was solubilized with skim milk before use. The starter 


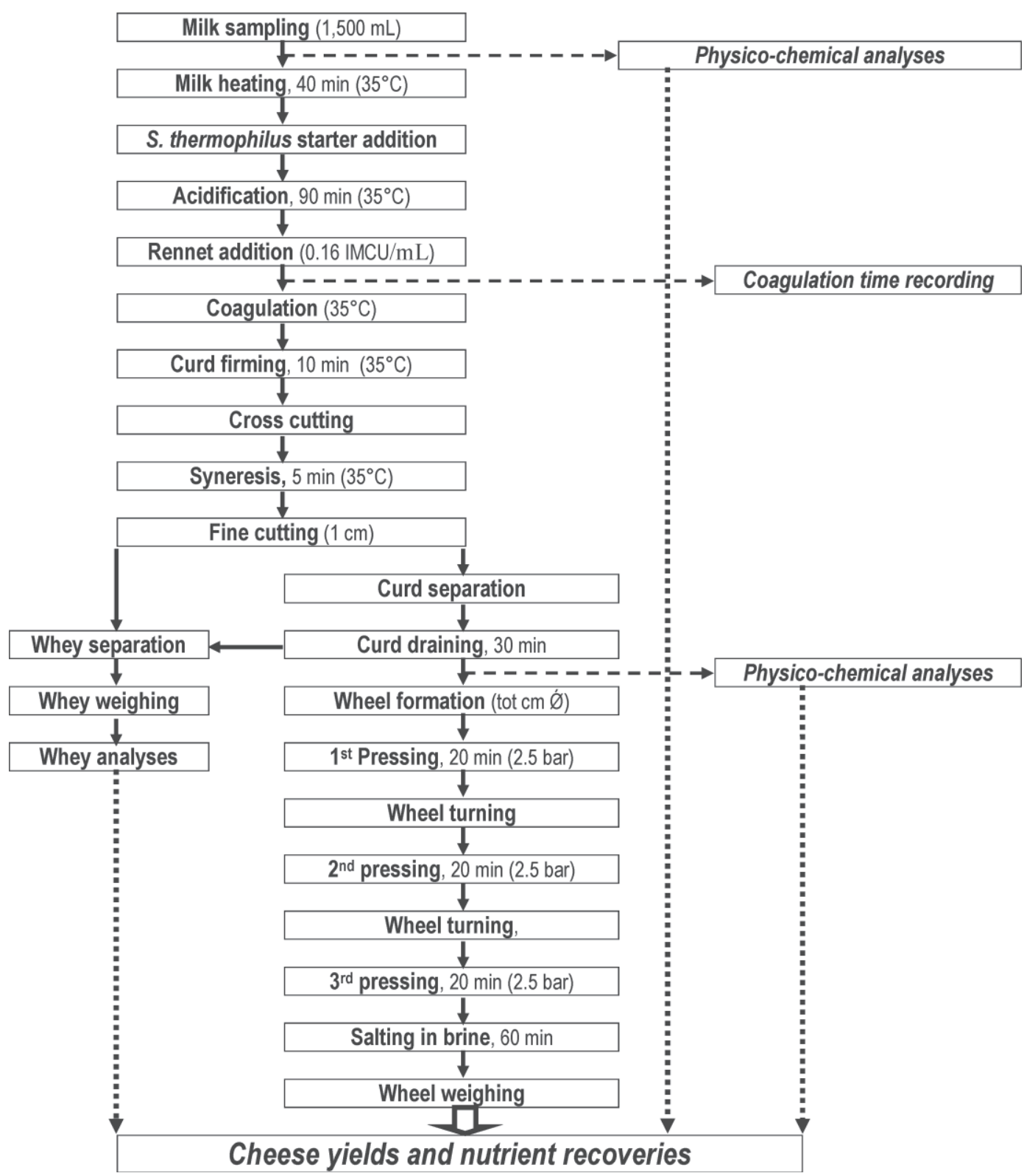

Figure 1. Flowchart for the micro model cheese-making.

culture was used at a concentration 8-fold higher than recommended to reduce the acidification time to 90 min and minimize the role of the microflora present in the milk samples. Commercial rennet [Hansen standard 160 with $80 \pm 5 \%$ chymosin and $20 \pm 5 \%$ pepsin; 160 international milk clotting units (IMCU) $/ \mathrm{mL}$; Pacovis Amrein AG, Bern, Switzerland] was diluted 20:1 with distilled water, and $9.6 \mathrm{~mL}$ of rennet solution was added to each vat (final concentration of 51.2 IMCU/L of milk). Milk rennet coagulation time was detected by visual observation of gelation of milk with the aid of a spoon. Ten minutes after gelation, the curd was cut, using a vertical cross cut centered on the vertical axis of the vat. Five minutes after the first cut, the curd was reduced into cubes of about $1 \mathrm{~cm}^{3}$. After $5 \mathrm{~min}$, the curd was separated from the whey and suspended on a cheese mold for $30 \mathrm{~min}$; the mold was suspended over the whey-containing vat and the curd was turned every $2 \mathrm{~min}$ to facilitate draining. After draining, the whey was weighed and sampled for analysis of $\mathrm{pH}$ and composition using a MilkoScan FT2 (Foss). The curd was pressed for $60 \mathrm{~min}$ at $250 \mathrm{kPa}$ with turning every $20 \mathrm{~min}$. Finally, the curd was salted for $60 \mathrm{~min}$ in brine (saturated solution; $20 \% \mathrm{NaCl}$ ). After brining, 
the cheese wheel was weighed, the $\mathrm{pH}$ was measured, and the composition was determined using a FoodScan (Foss). The $\mathrm{pH}$ values of the curd and whey were measured using a Crison Basic 20 electrode (Crison).

\section{Definition of Traits}

All assessed traits were based on the weights and chemical compositions of the milk, whey, and daily milk yield of cows. The classical formula for cheese yield ( $\left.\mathbf{C}_{\mathbf{C Y}} \mathbf{C U R D}_{\mathbf{C}}, \%\right)$ can be written as follows:

$$
\% \mathrm{CY}_{\mathrm{CURD}}=\frac{\text { weight of wheel }(\mathrm{g})}{\text { weight of milk }(\mathrm{g})} \times 100 \text {. }
$$

The weight of the wheel was taken after brining.

Cheese yield was also calculated for total solids (TS; $\left.\mathbf{\% C Y}_{\text {SOLIDS }}, \%\right)$ and water $\left(\boldsymbol{\%} \mathbf{C Y}_{\text {WATER }}, \%\right)$ of the curd, as follows:

$$
\begin{gathered}
\% \mathrm{CY}_{\text {SOLIDS }}=\frac{\text { milk TS }(\mathrm{g})-\text { whey TS }(\mathrm{g})}{\text { weight of milk }(\mathrm{g})} \times 100, \\
\% \mathrm{CY}_{\text {WATER }}=\frac{\text { milk water }(\mathrm{g})-\text { whey water }(\mathrm{g})}{\text { weight of milk }(\mathrm{g})} \times 100 \text {. }
\end{gathered}
$$

Considering the weight $(\mathrm{g})$ of the individual components of the milk and curd, the recoveries (REC; \%) of milk protein, fat, and TS in the curd were calculated as

$$
\begin{gathered}
\operatorname{REC}_{\text {Protein }}(\%)=\frac{\text { milk protein }(\mathrm{g})-\text { whey protein }(\mathrm{g})}{\text { milk protein }(\mathrm{g})} \times 100, \\
\operatorname{REC}_{\mathrm{FAT}}(\%)=\frac{\text { milk fat }(\mathrm{g})-\text { whey fat }(\mathrm{g})}{\text { milk fat }(\mathrm{g})} \times 100, \\
\operatorname{REC}_{\text {SOLIDS }}(\%)=\frac{\text { milk TS }(\mathrm{g})-\text { whey TS }(\mathrm{g})}{\text { milk TS }(\mathrm{g})} \times 100 .
\end{gathered}
$$

The recovery of energy in the curd was also calculated using

$$
\operatorname{REC}_{\text {ENERGY }}(\%)=\frac{\text { milk energy }(\mathrm{kJ})-\text { whey energy }(\mathrm{kJ})}{\text { milk energy }(\mathrm{kJ})} \times 100 \text {. }
$$

The energy of milk and whey was calculated using the values proposed by the NRC (2001) and converted to kilojoules per gram (fat $=38.89 \mathrm{~kJ} / \mathrm{g}$; protein $=23.90$ $\mathrm{kJ} / \mathrm{g}$; lactose $=16.53 \mathrm{~kJ} / \mathrm{g}$ ). The energy of the curd $(\mathrm{kJ} / \mathrm{g})$ was estimated as the difference between the energy of the milk and whey.
The daily cheese yields of a cow $(\mathrm{kg} / \mathrm{d})$ were also calculated:

$$
\begin{aligned}
\mathrm{dCY}_{\text {CURD }} & =\mathrm{MY}(\mathrm{kg} / \mathrm{d}) \times \% \mathrm{CY}_{\text {CURD }} \times 100^{-1}, \\
\mathrm{dCY}_{\text {SOLIDS }} & =\mathrm{MY}(\mathrm{kg} / \mathrm{d}) \times \% \mathrm{CY}_{\text {SOLIDS }} \times 100^{-1}, \\
\mathrm{dCY}_{\text {WATER }} & =\mathrm{MY}(\mathrm{kg} / \mathrm{d}) \times \% \mathrm{CY}_{\text {WATER }} \times 100^{-1},
\end{aligned}
$$

where MY is the daily milk yield of individual cow.

\section{Statistical Analysis}

Data were analyzed using the MIXED procedure (SAS Institute Inc., Cary, NC) according to the following linear model:

$$
\begin{aligned}
y_{i j k l m n}=\mu & + \text { DIM }_{i}+\text { parity }_{j}+\text { vat } / \text { waterbath }_{k} \\
& +M Y_{l}+\text { Herd }_{m}+e_{i j k l m n},
\end{aligned}
$$

where $y_{i j k l m n}$ is the observed trait $\left(\% \mathrm{CY}_{\mathrm{CURD}}\right.$, $\% \mathrm{CY}_{\text {SOLIDS }}, \quad \% \mathrm{CY}_{\text {WATER }}, \quad \mathrm{REC}_{\text {PROTEIN }}, \mathrm{REC}_{\mathrm{FAT}}$, REC $_{\text {SOLIDS }}, \mathrm{REC}_{\text {ENERGY }}, \mathrm{dCY}_{\text {CURD }}, \mathrm{dCY}_{\text {SOLIDS }}$, or $\left.\mathrm{d} C \mathrm{Y}_{\text {WATER }}\right) ; \mu$ is the overall intercept of the model; $D I M_{i}$ is the fixed effect of the $i$ th class of DIM $(i=1$ to 10; class 1: $<30 \mathrm{~d}$, class 2: 30-60 d, class 3: $61-90 \mathrm{~d}$; class 4: $91-120 \mathrm{~d}$; class 5 : $121-150 \mathrm{~d}$; class 6 : $151-180 \mathrm{~d}$; class 7: 181-210 d; class 8: 211-240 d; class 9: 241-300 $\mathrm{d}$; class 10: $>300 \mathrm{~d}$ ); parity $_{j}$ is the fixed effect of the $j$ th parity of the cow ( $j=1$ to 5 or more); vat/waterbath $h_{k}$ is the fixed effect of the $k$ th number of the vat or waterbath $(k=1$ to 15$) ; M Y_{l}$ is the fixed effect of $l$ th class of single test-day milk yield ( $l=1$ to 7 : class $1 \leq 14.48$; class 2: 14.49-18.43; class 3: 18.44-22.37; class 4: 22.3826.31; class 5: 26.32-30.26; class 6: 30.27-34.20; class 7 $\geq 34.21$ ); Herd $_{m}$ is the random effect of the $m$ th herd ( $m$ $=1$ to 85 ) and $e_{i j k l m n}$ is the random residual. Herd and residuals were assumed to be independently and normally distributed with a mean of zero and variance $\sigma_{H}^{2}$ and $\sigma_{e}^{2}$, respectively. Percentage of variance explained by herd was calculated by dividing the corresponding component of variance by the total variance.

\section{RESULTS}

\section{Characteristics of Individual Samples}

Table 1 shows descriptive statistics for single test-day milk yield (MY) and for composition and acidity of milk, whey, and curd. Mean MY and SCS were 24.34 $\mathrm{kg} / \mathrm{d}$ and 2.98, respectively, and showed large coefficients of variation (CV; 32.4 and $62.4 \%$, respectively). 
Table 1. Descriptive statistics of single test-day milk yield, composition, and acidity for milk, whey, and curd $(\mathrm{n}=1,167)$

\begin{tabular}{|c|c|c|c|c|c|c|}
\hline \multirow[b]{2}{*}{ Trait } & \multicolumn{2}{|c|}{ Milk } & \multicolumn{2}{|c|}{ Whey } & \multicolumn{2}{|c|}{ Curd } \\
\hline & Mean & $\mathrm{CV}$ & Mean & $\mathrm{CV}$ & Mean & $\mathrm{CV}$ \\
\hline Milk yield, $\mathrm{kg} / \mathrm{d}$ & 24.34 & 32.4 & - & - & - & - \\
\hline TS, \% & 13.89 & 7.6 & 7.79 & 4.2 & 48.38 & 9.9 \\
\hline Fat, $\%$ & 4.38 & 20.5 & 0.53 & 41.9 & 26.17 & 19.3 \\
\hline Protein, \% & 3.75 & 11.4 & 0.97 & 16.0 & 19.51 & 8.5 \\
\hline Lactose, \% & 4.77 & 5.0 & 5.15 & 4.2 & 2.59 & 50.1 \\
\hline $\mathrm{pH}$ & 6.64 & 1.3 & 6.42 & 2.2 & 6.22 & 3.6 \\
\hline SCS ${ }^{1}$ units & 2.98 & 62.4 & - & - & - & - \\
\hline
\end{tabular}

${ }^{1} \mathrm{SCS}=\log _{2}(\mathrm{SCC} \times 100,000)+3$.

The milk fat, protein, casein, and lactose contents of Brown Swiss milk averaged 4.38, 3.75, 2.88, and 4.77\%, respectively. The contents of fat and protein in the whey were, respectively, slightly higher than $0.5 \%$ and slightly lower than 1.0\%; together with lactose and minerals, they contributed to an average TS content of $7.79 \%$. The average cheese fat, protein, and lactose contents obtained using our individual model-cheese production procedure were $26.17,19.51$ and $2.59 \%$, respectively (lactose content of the curd was obtained by the difference between the absolute lactose content of milk and whey divided by the weight of curd), contributing to a TS content of almost $50 \%$. The CV for milk, whey, and curd were greater than that of fat, followed by protein, TS, lactose, and $\mathrm{pH}$; the only exception was the lactose content of curd, which showed a high CV but a low average value.

Figures 2, 3, and 4 give the mean, standard deviation, and corresponding distributions of raw data and kurtosis and skewness estimated using model residuals. The mean for $\% \mathrm{CY}_{\mathrm{CURD}}$ after brining was $14.97 \%$, whereas those of $\% \mathrm{CY}_{\text {SOLIDS }}$ and $\% \mathrm{CY}_{\text {WATER }}$ were 7.18 and $7.77 \%$, respectively, each representing about half of $\mathrm{CY}_{\mathrm{CURD}}$; this was confirmed by the TS content of the curd, which was $48.38 \%$ (Figure 2). The CV for $\% \mathrm{CY}_{\text {WATER }}$ was higher $(16.34 \%)$ than corresponding values for $\% \mathrm{CY}_{\mathrm{CURD}}$ and $\% \mathrm{CY}_{\text {SOLIDS }}$ (12.42 and 12.81, respectively). All the traits were almost normally distributed (Figure 2), with kurtosis and skewness values (estimated using model residuals) close to zero. The recoveries of protein, fat, TS, and energy averaged 78.08, $89.79,51.88$, and $67.19 \%$, respectively (Figure 3). All of the recoveries exhibited SD higher than those of the \%CY, but had lower CV (3.1\% for protein recovery and $6.8 \%$ for TS). Only $\mathrm{REC}_{\mathrm{FAT}}$ yielded a clearly nonnormal distribution, with kurtosis and skewness of 1.216 and -0.848 , respectively; this may be explained by the proximity of the raw mean value to $100 \%$. The dCY values, expressed as cheese produced per cow, averaged $3.63,1.74$, and $1.88 \mathrm{~kg} / \mathrm{d}$, for $\mathrm{dCY}_{\mathrm{CURD}}, \mathrm{dCY}_{\text {SOLIDS }}$, and
$\mathrm{dCY}$ WATER respectively, whereas the corresponding SD were $1.17,0.57$, and $0.63 \mathrm{~kg} / \mathrm{d}$, respectively (Figure 4 ).

\section{Factors Affecting Variation of \%CY, REC, and dCY}

The results from our analysis of the effects included in the linear model are given in Table 2. Considering the $\% \mathrm{CY}$ traits, DIM was the most important source of variation, showing the highest $F$-values $(P<0.001)$. For all $3 \% \mathrm{CY}$ traits, lactation showed a trend opposite that of milk yield, with \%CY values decreasing from the first to second month of lactation and gradually increasing thereafter (Figure 5a). The maximum differences between the least squares means of the peak (second class) and the end of lactation were 2.14, 0.94, and $1.19 \%$, for $\% \mathrm{CY}_{\mathrm{CURD}}, \% \mathrm{CY}_{\text {SOLIDS }}$, and $\% \mathrm{CY}_{\text {WATER }}$, respectively. All \%CY traits were highly influenced by the herd-test-date, especially the yield of water in the curd: the proportion of the $\% \mathrm{CY}$ variance explained by this effect exhibited values of $0.32,0.24$, and 0.42 for $\% \mathrm{CY}_{\mathrm{CURD}}, \% \mathrm{CY}_{\mathrm{SOLIDS}}$, and $\% \mathrm{CY}_{\mathrm{WATER}}$, respectively. The effect of parity was not significant for $\% \mathrm{CY}_{\text {SOLIDS }}$, whereas $\% \mathrm{CY}_{\mathrm{CURD}}$ decreased from first- to third-parity cows, mainly because of a reduction of \% $\mathrm{CY}_{\text {WATER }}$ (Figure 6a). Considering recoveries, DIM was the most important effect for all REC values except for $\mathrm{REC}_{\text {PROTEIN }}$. Whereas $\mathrm{REC}_{\mathrm{FAT}}$ showed important differences during lactation, decreasing $2.96 \%$ until midlactation, $\mathrm{REC}_{\text {PROTEIN }}$ had a much lower variability with respect to lactation (Figure $5 \mathrm{~b}$ ). Both $\mathrm{REC}_{\text {SOLIDS }}$ and $\mathrm{REC}_{\text {ENERGY }}$ exhibited trends similar to those of the $\mathrm{CY}$ values, with the highest values seen at the end of lactation (Figure 5c). We observed an important effect of parity for $\operatorname{REC}_{\text {PROTEIN }}(P<0.001)$, with this trait decreasing in the older cows (Figure 6b). For the other REC traits, this source of variation was not significant. The effect of herd-test-date showed an important variability for REC values; the proportion of variance explained by this effect showed values from $0.21\left(\mathrm{REC}_{\mathrm{ENERGY}}\right)$ to $0.31\left(\mathrm{REC}_{\mathrm{FAT}}\right)$. The $3 \mathrm{dCY}$ 
a)

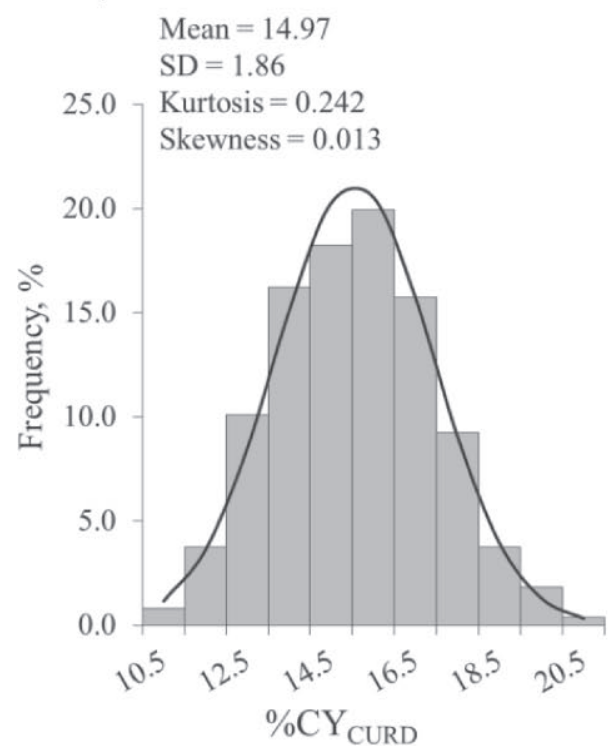

b)

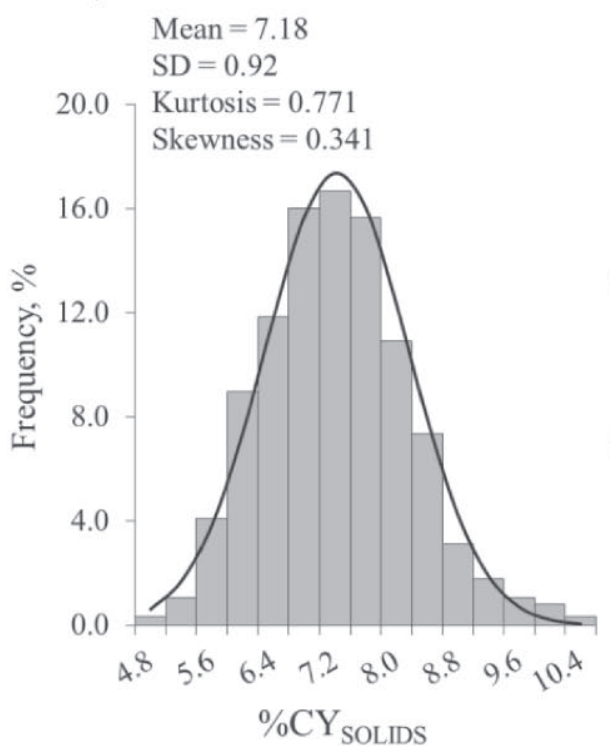

c)

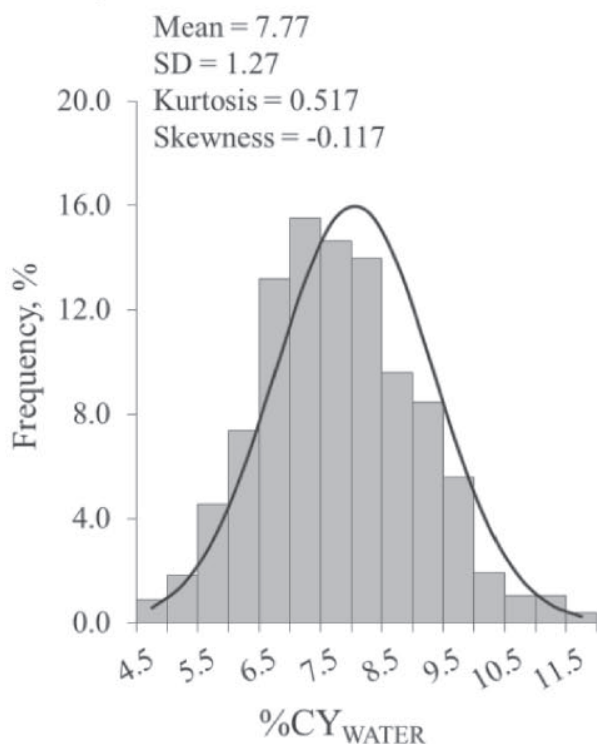

Figure 2. Distribution, mean, and standard deviation values of percentage cheese yield (\%CY): (a) $\% \mathrm{CY}_{\mathrm{CURD}}$, (b) \%CY $\mathrm{COLLIDS}_{\text {, and }}$ (c) $\% \mathrm{CY}_{\text {WATER }}$; skewness and kurtosis were estimated using model residuals.

traits were much more affected than the corresponding \%CY traits by both DIM and parity (Table 2), almost overlapping the classical trend that characterizes daily milk yield in relation to the stage of lactation (Figure $5 \mathrm{~d}$ ) and number of lactations (Figure 6d). The effect of vat was significant $(P<0.05)$ only for $\% \mathrm{CY}_{\text {SOLIDS }}$, $\mathrm{REC}_{\text {PROTEIN }}, \mathrm{REC}_{\text {SOLIDS }}$, and $\mathrm{REC}_{\text {ENERGY }}$, emphasizing that the micro cheese-making procedure used here exhibited acceptable reproducibility between vats.

\section{DISCUSSION}

\section{Model Cheese-Making Procedure}

Numerous attempts have been made to mimic the complex processes of cheese-making on a small scale in the laboratory setting. Many different procedures have been proposed, ranging from very simple protocols to techniques such as that used in the present study that resemble the industrial processes. All of these methods have been based on the steps of milk heating, enzyme addition, whey separation, and curd weighing.

In general, the simpler protocols use very small amounts of milk, stop the coagulation and syneresis processes at a fixed time from enzyme addition rather than from coagulation time (which is not recorded), and use centrifugation for whey separation. These techniques allow the simultaneous processing of many samples but do not allow analysis of different characteristics of individual model cheeses. For example, Hurtaud et al. (1995) described a procedure in which $100-\mathrm{mL}$ milk samples were incubated in an oven for $1 \mathrm{~h}$ after enzyme addition. Othmane et al. (2002) simultaneously evaluated cheese yield from 60 individual samples of ewe milk (10 mL), using Pyrex glass tubes as individual vats. The most extreme technique was used by Bachmann et al. (2009), who screened starter cultures using as little as $1.7 \mathrm{~mL}$ of milk (average curd weight of 0.17 $\mathrm{g})$. Instead of individual vats, the researchers used the wells of a 2-mL deep-well microplate, which allowed them to process up to 600 samples per run.

The protocols closer to industrial processes are typically carried out on larger amounts of milk, coagulation and syneresis are stopped at a fixed time from enzyme addition or from coagulation time (which may be recorded, as in the present study), and the curd is drained and pressed for whey separation. These techniques, such as that reported here, allow the simultaneous processing of relatively few samples, but enable researchers to analyze individual model cheeses. The quantity of milk used in such processes has varied. In the current study, we used 1,500-mL, whereas Pereira et al. (2010) processed 200-mL samples in glass flasks using an oven; Cologna et al. (2009) processed 500-mL samples in stainless steel mini-vats using a water bath; Marziali and Ng-Kwai-Hang (1996) processed 2,000-mL samples in plastic containers in a water bath; Milesi et al. (2007) processed 2,000-mL samples in large glass flasks incubated in a water bath; Wedholm et al. (2006) processed 4,000-mL samples in laboratory-scale cheese vats; and Fagan et al. (2007) and Jacob et al. (2010) processed $7,000-\mathrm{mL}$ samples in laboratory-scale cheese 

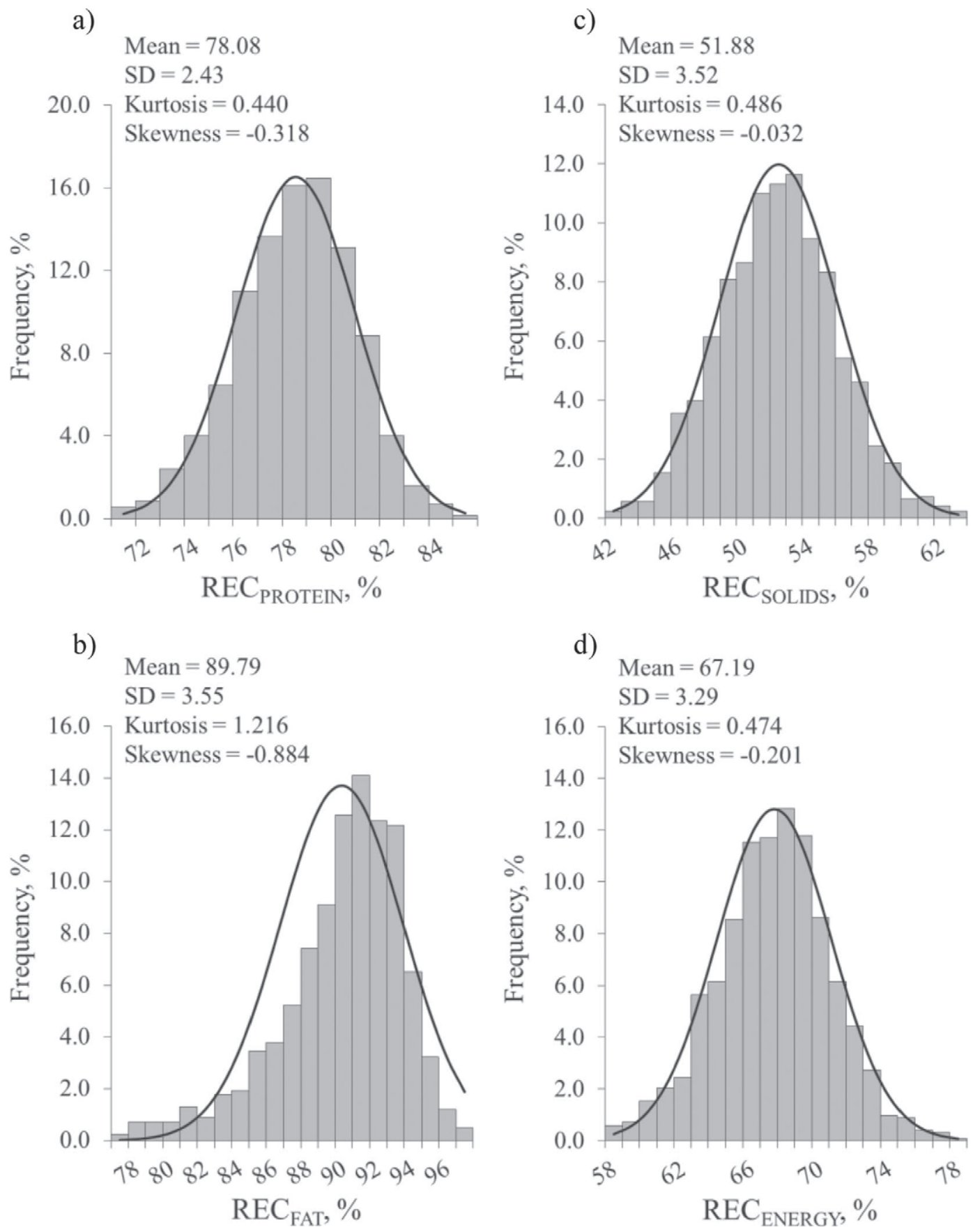

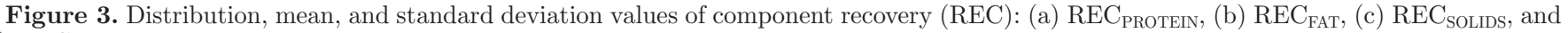
(d) REC $_{\text {ENERGY; }}$ skewness and kurtosis were estimated using model residuals.

vats. Some researchers have applied even larger scales for the production of model cheeses, such as the use of more than $30 \mathrm{~L}$ of milk in pilot-scale cheese plants to study the effects of breed (Verdier et al., 1995; Mistry et al., 2002; Martin et al., 2009), feeding regimen (Kefford et al., 1995; Verdier et al., 1995; Hurtaud et al.,
2009), and cheese-making technique (Johnson et al., 2001; Jacob et al., 2010).

The different model cheese procedures were not compared in terms of repeatability and reproducibility, even though it is expected that increasing the amount of milk processed would decrease the relative magni- 

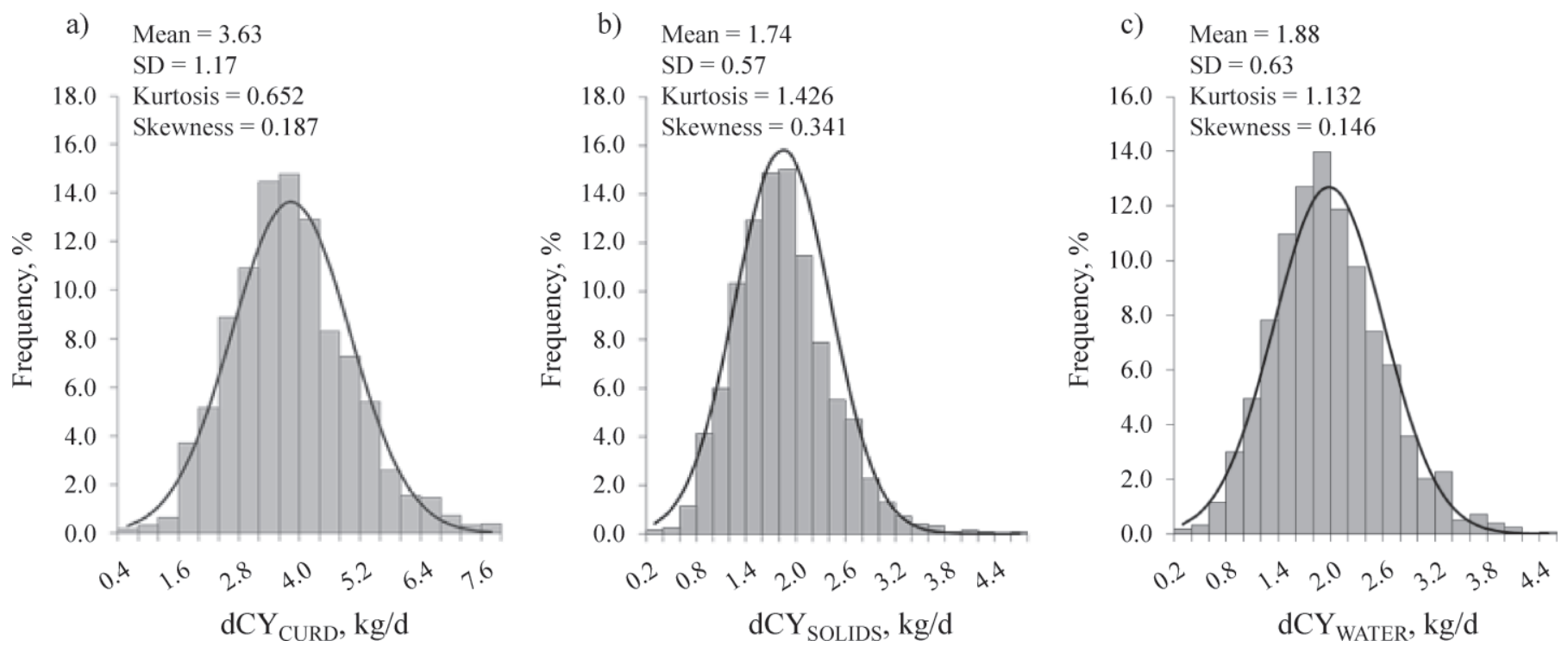

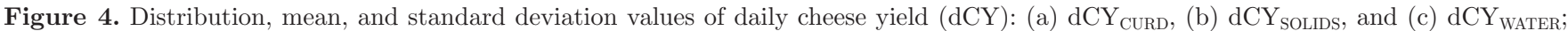
skewness and kurtosis were estimated using model residuals.

tude of measurement error between samples of different sizes.

\section{Cheese Yield}

The average fresh cheese yield percentage obtained in the present study $(15.0 \%)$ is higher than that often found in the literature. This is primarily because we used milk from Brown Swiss cows. The milk produced by Brown Swiss cows is used mainly for the production of traditional cheeses that can obtain the Protected Designation of Origin certification from the European Union (Bittante et al., 2011a,b). In this case, the quality of the milk (in terms of contents and technological properties) is fundamental, and cheese yield and quality are the most important traits in determining milk price. Italian Brown Swiss cows are currently selected mainly according to protein yield and percentage of

Table 2. Results from ANOVA ( $F$-value and significance) for cheese yields $(\% \mathrm{CY})$ and milk component recoveries (REC)

\begin{tabular}{|c|c|c|c|c|c|c|c|c|}
\hline \multirow[b]{3}{*}{ Trait } & \multicolumn{7}{|c|}{ Effect } & \multirow[b]{3}{*}{ RMSE } \\
\hline & \multicolumn{2}{|c|}{ DIM } & \multicolumn{2}{|c|}{ Parity } & \multicolumn{2}{|c|}{ Vat/WB ${ }^{2}$} & \multirow[b]{2}{*}{$\mathrm{HTD}^{3}, \%$} & \\
\hline & $F$-value & $P$-value & $F$-value & $P$-value & $F$-value & $P$-value & & \\
\hline \multicolumn{9}{|l|}{$\% \mathrm{CY}$} \\
\hline Curd & 16.72 & $* * *$ & 4.87 & $* * *$ & 1.13 & NS & 32 & 1.40 \\
\hline Solids & 13.18 & $* * *$ & 1.44 & NS & 1.84 & $*$ & 24 & 0.75 \\
\hline Water & 11.04 & $* * *$ & 6.63 & $* * *$ & 1.20 & NS & 42 & 0.91 \\
\hline \multicolumn{9}{|l|}{ REC, \% } \\
\hline Protein & 3.36 & $* * *$ & 21.26 & $* * *$ & 0.85 & $*$ & 28 & 1.97 \\
\hline Fat & 7.29 & $* * *$ & 0.91 & NS & 1.26 & NS & 31 & 2.89 \\
\hline Solids & 13.82 & $* * *$ & 0.78 & NS & 1.95 & $*$ & 23 & 2.86 \\
\hline Energy & 4.67 & $* * *$ & 0.21 & NS & 1.82 & $*$ & 21 & 2.85 \\
\hline \multicolumn{9}{|c|}{ Production trait, ${ }^{4} \mathrm{~kg} / \mathrm{d}$} \\
\hline $\mathrm{dCY} \mathrm{CURD}_{\mathrm{C}}$ & 40.74 & $* * *$ & 19.20 & $* * *$ & 1.24 & NS & 53 & 0.54 \\
\hline $\mathrm{dCY}_{\text {SOLIDS }}$ & 39.64 & $* * *$ & 24.36 & $* * *$ & 1.63 & $\mathrm{NS}$ & 51 & 0.13 \\
\hline $\mathrm{dCY}_{\text {WATER }}$ & 34.11 & $* * *$ & 13.55 & $* * *$ & 0.88 & $\mathrm{NS}$ & 53 & 0.16 \\
\hline
\end{tabular}

${ }^{1} \mathrm{RMSE}=$ root means square error.

${ }^{2} \mathrm{WB}=$ waterbath.

${ }^{3}$ Herd-test-day effect expressed as proportion of variance explained by herd-test-date calculated by dividing the corresponding variance component by the total variance.

${ }^{4} \mathrm{dCY}=$ daily cheese yield

${ }^{*} P<0.05 ;{ }^{* * *} P<0.001$. 
a)

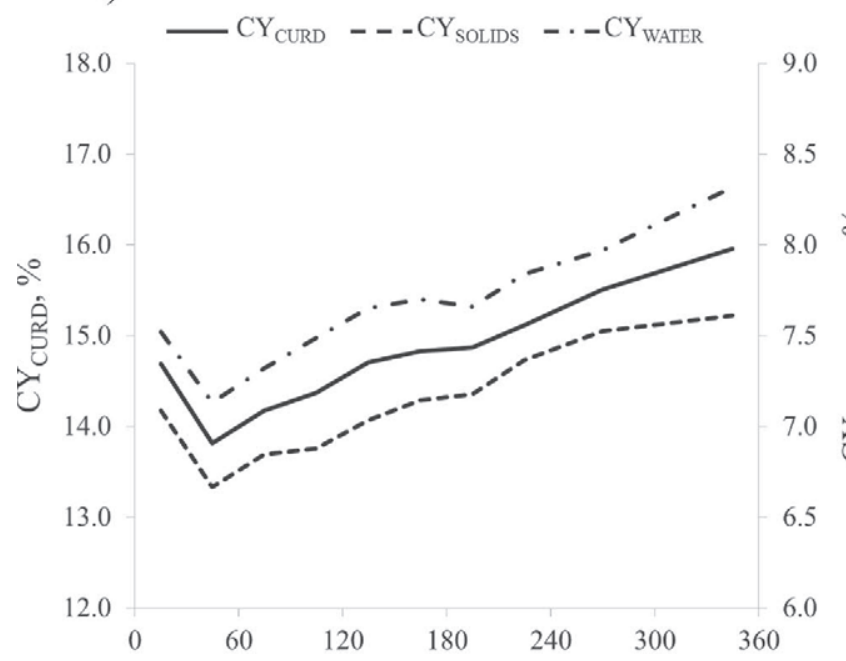

b)

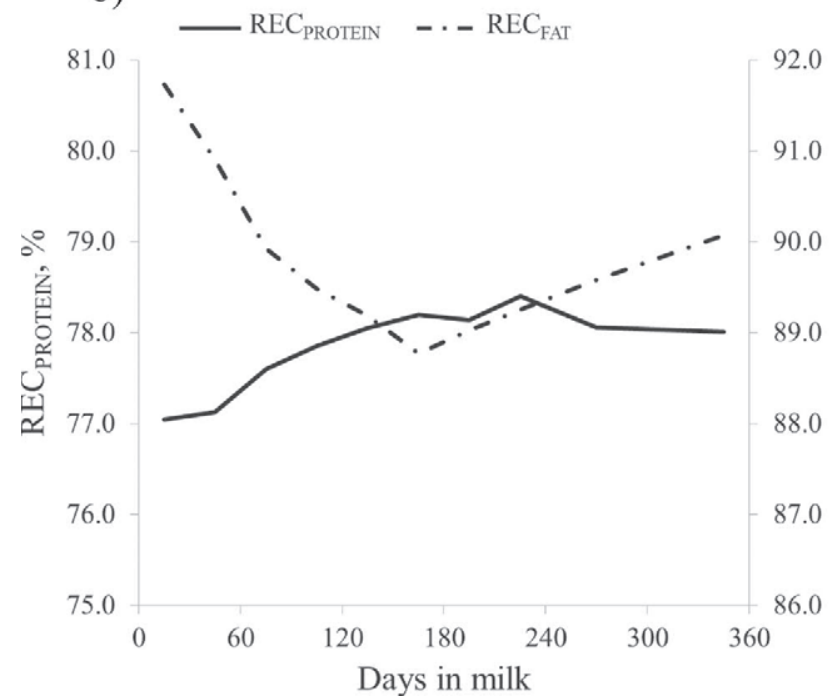

c)

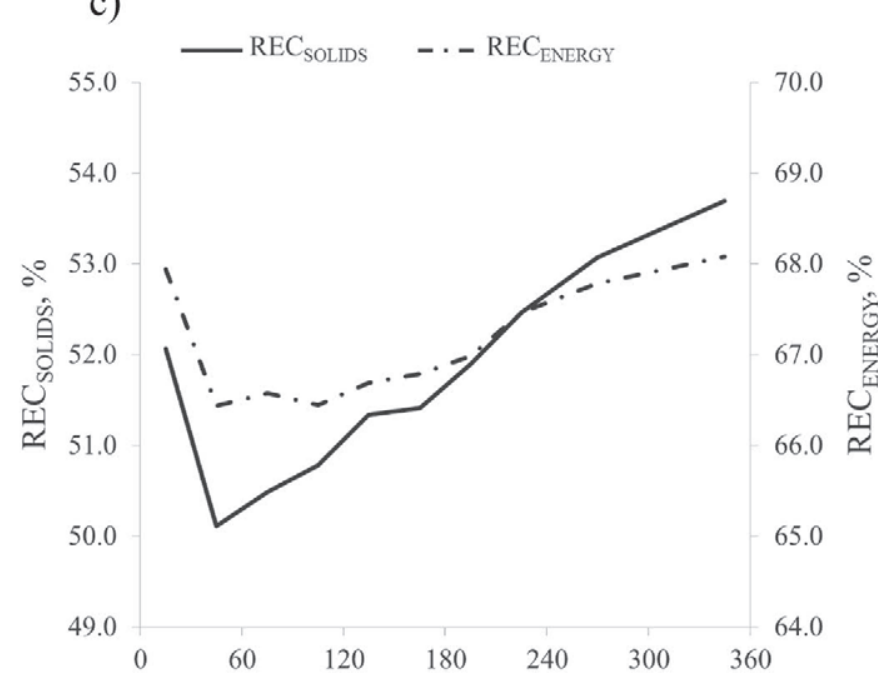

d)

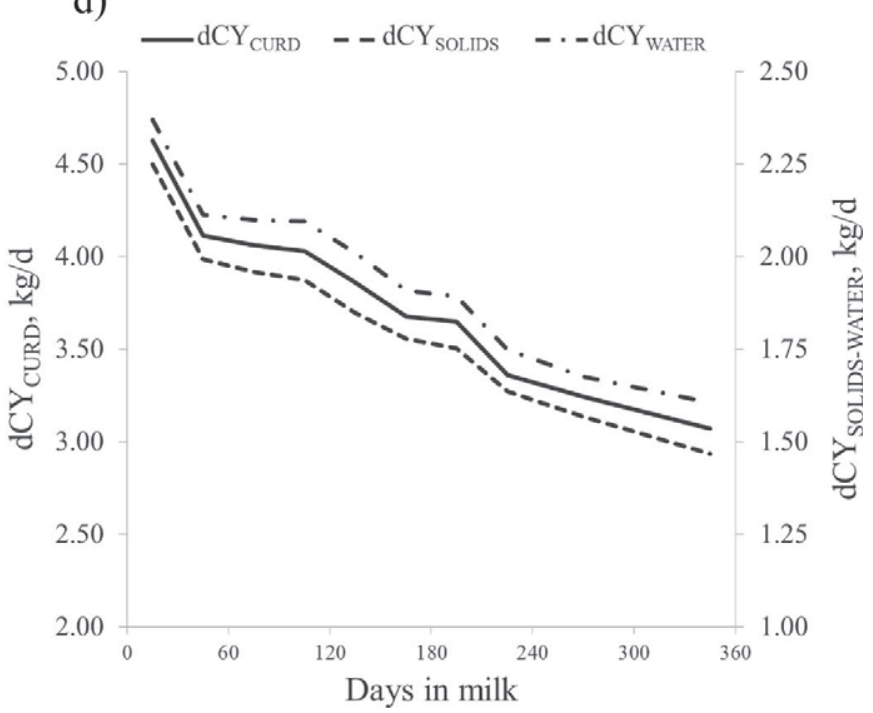

Figure 5. Least squares means of (a) $\% \mathrm{CY}_{\mathrm{CURD}}, \% \mathrm{CY}_{\mathrm{SOLIDS}}, \mathrm{CY}_{\mathrm{WATER}} ;$ (b) REC $\mathrm{R}_{\mathrm{PROTEIN}}$, REC $\mathrm{RAT}$; (c) REC $\mathrm{R}_{\mathrm{SOLIDS}}$, REC $\mathrm{R}_{\mathrm{ENERGY}}$, and

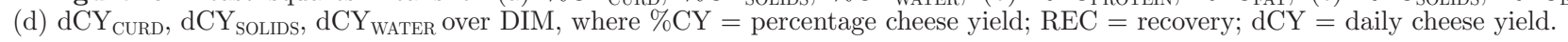

milk (ANARB, 2011). This selection strategy explains the high protein and casein contents of the milk used in the present research (Table 1) and confirms results obtained by other authors in the same breed (Samoré et al., 2007, 2012). The B allele of the CSN3 gene (encoding $\kappa$-casein) is also included in the selection index. This is intended to favor the further improvement of the good coagulation properties (Penasa et al., 2010) that characterize milk from Brown Swiss cows (Cecchinato et al., 2011; Bittante et al., 2012). Moreover, the breed has favorable genetic characteristics in regard to milkability, fertility, and longevity (Povinelli et al., 2003; Tiezzi et al., 2011, 2012).

The value of $\% \mathrm{CY}_{\mathrm{CURD}}$ was significantly higher in first- and second-calving cows compared with older cows (Figure 6a) and increased almost linearly from the second month to the end of lactation (Figure 5a), whereas $\mathrm{dCY}_{\mathrm{CURD}}$ showed the opposite trends both for parity (Figure 6d) and DIM (Figure 5d), confirming the negative relationships usually found between qualitative $(\% \mathrm{CY})$ and quantitative $(\mathrm{dCY})$ traits.

The effect of herd was important for $\% \mathrm{CY}_{\mathrm{CURD}}$; in fact, it explains $32 \%$ of the total variance of the trait, and was more important for dCY (explaining $53 \%$ of the total variance), even after we corrected for parity and DIM. Herd is generally accepted as summarizing the effects on $\% \mathrm{CY}_{\mathrm{CURD}}$ of farm type, feeding regimen (Kefford et al., 1995; Verdier-Metz et al., 1998), and season (Bynum and Olson, 1982; Summer et al., 2003). 
a)

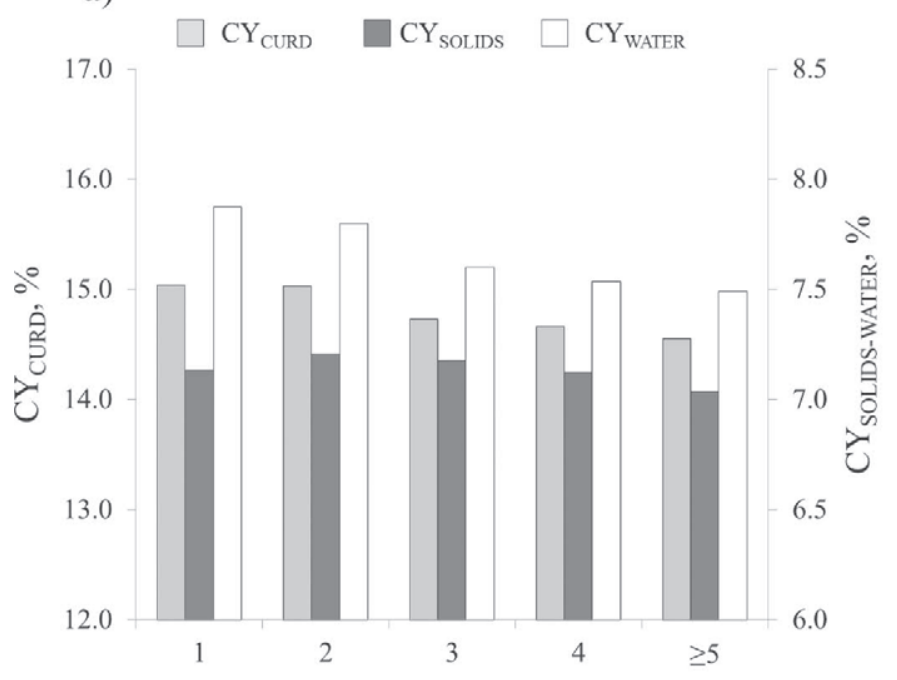

b)

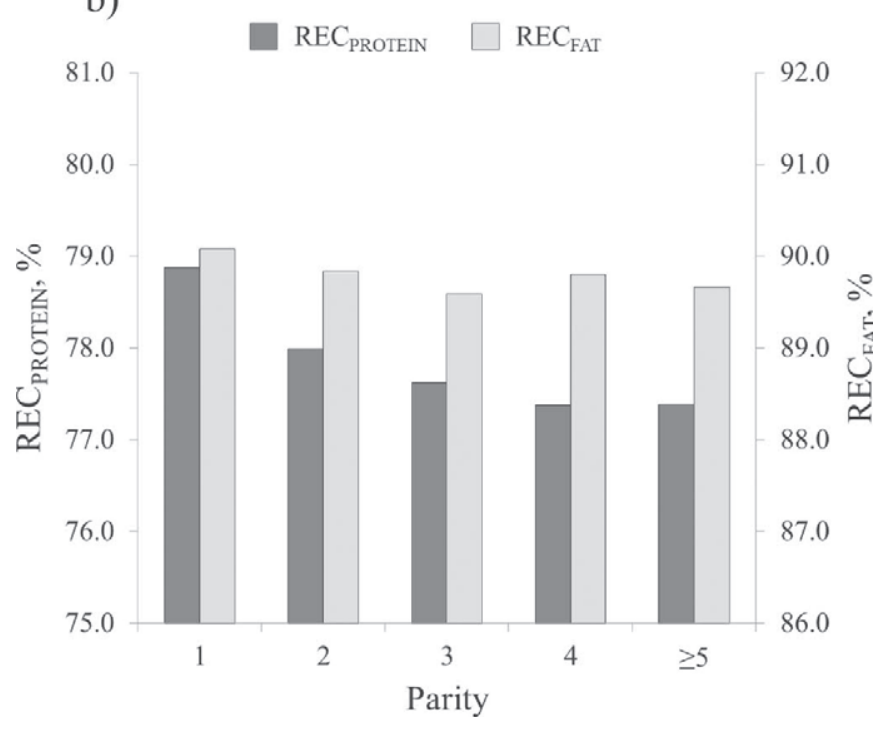

c)

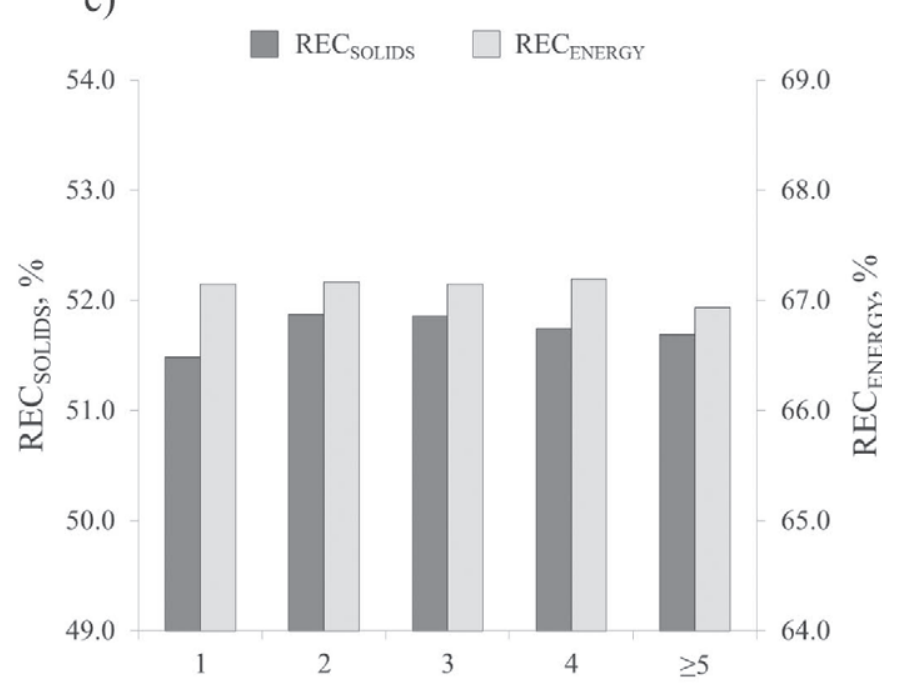

d)

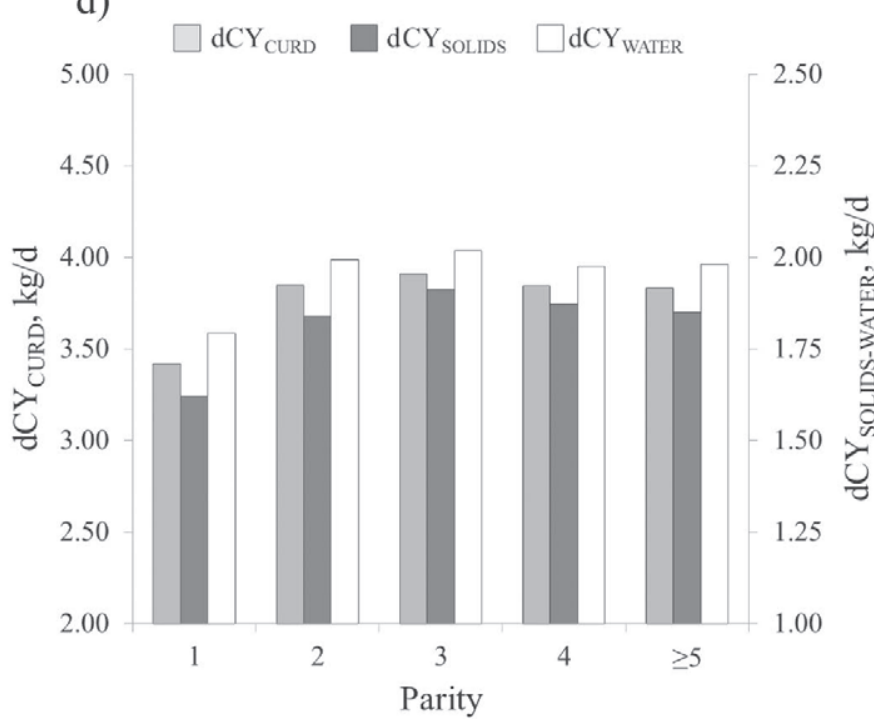

Figure 6. Least squares means of (a) $\mathrm{CY}_{\mathrm{CURD}}, \mathrm{CY}_{\mathrm{SOLIDS}}, \mathrm{CY}_{\text {WATER }}$; (b) $\mathrm{REC}_{\mathrm{PROTEIN}}, \mathrm{REC}_{\mathrm{FAT}}$; (c) $\mathrm{REC}_{\mathrm{SOLIDS}}, \mathrm{REC}_{\text {ENERGY}}$; and (d) dCY $\mathrm{dURD}_{\text {, }}$ $\mathrm{dCY}_{\text {SOLIDS }}, \mathrm{dCY} \mathrm{Y}_{\text {WATER }}$ across parities, where $\% \mathrm{CY}=$ percentage cheese yield; $\mathrm{REC}=$ recovery; $\mathrm{dCY}=$ daily cheese yield.

\section{Total Solids and Water Retention in Cheese}

Water retention in cheese varies and is influenced mainly by processing conditions, such as the type and concentration of rennet, the cutting time and intensity, the draining and pressing of wheels, the salting technique, and the length and climatic conditions of ripening (Remeuf et al., 1991; Janhøj and Qvist, 2010; Everard et al., 2011). To exclude the effect of variations in the water content of the cheese, some researchers have calculated the TS cheese yield percentage (or DM cheese yield), which is expressed as the ratio between the DM content of the cheese and the weight of the processed milk (Fagan et al., 2007).
In the case of model cheeses, it may not be feasible to analyze the chemical composition of the curd if a very small quantity of milk is used. In addition, the use of centrifugation to separate the whey from the curd means that water retention is not representative of that achieved through a standard cheese-making process. Thus, $\% \mathrm{CY}_{\text {SOLIDS }}$, and consequently also $\mathrm{dCY}_{\text {SOLIDS }}$, is more often obtained in larger model cheese-making processes, such as those performed in pilot plants during the study of processing techniques (Fagan et al., 2007; Jacob et al., 2010).

In the case of model cheeses produced using very small amounts of milk, only the procedure proposed by Melilli et al. (2002) is based on the direct estimation of 
$\% \mathrm{CY}_{\text {SOLIDS. }}$ However, those authors used this procedure to predict the results obtained with the formula of Van Slyke and Publow (1910), thus avoiding the need to analyze milk fat and protein. The average $\% \mathrm{CY}_{\text {SOLIDS }}$ obtained by Melilli et al. (2002) was $6.59 \%$, whereas that found in the present study was $7.18 \%$; this difference may be largely explained by differences in milk composition (3.83 vs. $4.38 \%$ for fat and 2.98 vs. $3.75 \%$ for protein, respectively).

The effect of herd, parity, and DIM on the amount of water retained in the curd as a fraction of the weight of processed milk (\% CY $\left.\mathrm{CATER}_{\text {WA }}\right)$ or as daily production of a cow $\left(\mathrm{dCY}_{\mathrm{WATER}}\right)$ has not previously been studied at the individual level. Total solids represented $48 \%$ of the fresh curd after brining, which was similar to the proportions found by other researchers using similar conditions (Verdier-Metz et al., 2001; Martin et al., 2009). Thus, water contributed slightly more than TS to both percentage and daily cheese yields ( 7.8 vs. $7.2 \%$, and 1.88 vs. $1.74 \mathrm{~kg} / \mathrm{d}$, respectively). The $\% \mathrm{CY}_{\text {WATER }}$ was also characterized by a higher phenotypic $\mathrm{CV}$ with respect to $\% \mathrm{CY}_{\text {SOLIDS }}$ (16.3 vs. $12.8 \%$, respectively), reflecting the expected large effect of herd-test-date (environmental effects on collection and processing of milk samples), whereas, in the case of dCY CV was much higher $(33.4 \%)$, reflecting that of MY $(32.4 \%)$, and very similar to that of dCY $\mathrm{C}_{\text {SOLIDS }}(32.9 \%)$. But $\mathrm{CY}_{\text {WATER }}(\%$ and $\mathrm{kg} / \mathrm{d}$ ) was also strongly affected by factors related to individual cows, such as DIM and parity.

\section{Protein Recovery in the Cheese and Losses in Whey}

Proteins play a fundamental role in the coagulation and syneresis processes that characterize cheese-making (Emmons et al., 2003), and the loss of proteins in whey reduce the cheese yield (Hallén et al., 2010). Since 1895 (Emmons and Modler, 2010), almost all the predictive formulas for estimating cheese yield have been based on knowledge of the protein (or casein/para-caseinate) and fat contents of milk (Van Slyke and Price, 1952; Banks et al., 1981, 1984; Emmons et al., 1990) or the sum of the fat and protein contents (Verdier-Metz et al., 2001). All of these formulas assume that the recovery of milk protein and fat in the curd is constant. However, this assumption is contradicted by the results obtained by Aleandri et al. (1989), who found a curvilinear relationship between the protein content of milk and Parmesan cheese yield.

The effects of farming conditions, cow feed (Summer et al., 2003), and cheese-making technologies (Bynum and Olson, 1982) on REC Protein have been widely studied, but few studies have examined the effects of individual sources of variation on this trait. Kefford et al. (1995) failed to find differences in $\mathrm{REC}_{\text {PROTEIN }}$ when examining cheese made from milk of mid- or latelactation cows. This is consistent with the results of the present study, as we found that $\mathrm{REC}_{\text {PROTEIN }}$ increased only during the initial stage of lactation.

The descriptive statistics in Figure 3a show that the average recovery of milk protein in curd after brining was almost identical to the casein number $(78.08$ vs. $78.05 \%$, respectively). However, the former trait had an appreciable CV (3.1\%), and previous studies showed that the recovery of casein in cheese can be substantially lower than $100 \%$, beyond the loss of glycomacropeptide and the part of whey proteins that are retained in the curd. For example, Bynum and Olson (1982) studied typical Cheddar cheese production and obtained a CP recovery of $88.6 \pm 2.34 \%$ with respect to the casein content of the processed milk. Ikonen et al. (1999) studied Emmental cheese production and

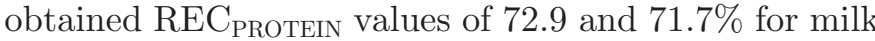
with good coagulation and a casein number of 79.7 compared with milk having poor coagulation and a casein number of 79.1, respectively. Summer et al. (2003), in a study on seasonal variations, and Malacarne et al. (2006), in a study comparing milk from Italian Friesian and Italian Brown Swiss cows, examined ParmigianoReggiano cheese production and found protein losses in whey of $26.8 \%$ and $26.8 \pm 1.0 \%$, respectively, casein indices of $77.4 \pm 0.9$, and $77.3 \pm 0.7$, respectively, and no significant effect of season or breed. Moreover, Bittante et al. (2013) analyzed the same data set as used in the present study and obtained high estimates for across-herd and within-herd heritability of $\mathrm{REC}_{\text {PROTEIN }}$ (35.3 and $49.0 \%$, respectively).

\section{Fat Recovery in Cheese and Losses in Whey}

The average fat recovery in the curd was close to $90 \%$. The reported variability in this measure is mainly related to the cheese-making technology, season, farming conditions, and feed (Bynum and Olson, 1982; Summer et al., 2003). Only a few results are available regarding individual phenotypic causes of variation. Among them, Kefford et al. (1995) found that $\mathrm{REC}_{\mathrm{FAT}}$ did not differ between milk from mid- and late-lactation cows.

The contribution of fat to coagulation and syneresis is less important than that of proteins, but fat recovery in the curd and losses in the whey are important for the final cheese yield, and are influenced by both coagulation and syneresis (Fagan et al., 2007).

The genetic effects of breed and milk protein variants have been discussed by Bittante et al. (2013). The same authors also reported, from an estimation based on the same data set used in the present study, that $\mathrm{REC}_{\mathrm{FAT}}$ is heritable, albeit to a lesser degree than $\mathrm{REC}_{\text {PROTEIN }}$ 
(0.14 and 0.21 for across-herd and within-herd heritability, respectively).

\section{Total Solids and Energy Recovery in Cheese and Losses in Whey}

Only slightly more than half of the TS present in milk (on average) is captured in the curd coagulum (Verdier et al., 1995; Kefford et al., 1995; Verdier-Metz et al., 1998), but it represents about two-thirds of the total energy content of milk (Figure $3 \mathrm{c}$ and $3 \mathrm{~d}$ ). Both $\mathrm{REC}_{\text {SOLIDS }}$ and $\mathrm{REC}_{\text {ENERGY }}$ are characterized by $\mathrm{CV}$ (6.8 and $4.9 \%$, respectively) greater than those of the major individual cheese components. A study carried out by Verdier et al. (1995) did not show any effect of breed or diet on REC $\mathrm{R}_{\text {SoLids }}$. However, a later study, Verdier-Metz et al. (1998), found that both factors had significant effects on this trait.

A large effect of the stage of lactation on $\mathrm{REC}_{\text {SOLIDS }}$ and the recovery of nonfat solids was found by Kefford et al. (1995), although their study involved cheesemaking carried out on bulk milk.

After correction for fat and protein contents, nutrient recoveries from milk and water retention in the curd can explain a large part of the residual variability in cheese yield, both between and within breeds. The importance of these findings was highlighted by research conducted in the same area as the present study (Trento Province, northeast Italy) on the production of 3 traditional Protected Designation of Origin cheeses. De Marchi et al. (2008) found that the cheese yields obtained using milk from Brown Swiss cows were higher than those obtained using milk from Holstein-Friesian cows reared in the same herds for the production of all the 3 cheese types. The same authors found that only part of the differences in cheese yield between the 2 breeds could be explained by differences in the fat and protein contents of the milk. Despite similar fat:casein ratios in the milk, comparison of Casolet cheese made from the milk of Brown Swiss cows versus Holstein Friesian cows showed that the former had greater superiority in cheese yield $(+12 \%)$ than in the protein content of milk $(+8.2 \%)$. The same was found for Vezzena cheese production (+17 vs. $+10 \%$, respectively) and Grana del Trentino (or Trentingrana) cheese production (+12 vs. $+7.7 \%$, respectively). Similar results were obtained by Martin et al. (2009) when comparing the cheese yields of Holstein and Montbeliarde cows in Cantal cheese production; only about half of the superiority of cheese yield from Montbeliarde milk was explained by its superiority in protein and fat content. In studies using milk standardized to a 1.15 fat:protein ratio from Holstein, Montbeliarde, and Tarentaise cows for the production of Saint-Nectaire cheese, however, Verdier et al. (1995) and Verdier-Metz et al. (1998) failed to find significant differences among the breeds in terms of CYCURD, although the latter study reported a difference in $\mathrm{REC}_{\text {SOLIDs }}$. Comparing Holstein and Jersey cows, which have similar milk coagulation properties, Auldist et al. (2004) found a higher $\mathrm{CY}_{\text {CURD }}$ for Jersey cows, which was expected given their differences in milk composition, but a similar "moisture-adjusted cheese yield/100 $\mathrm{kg}$ of milk solids" (similar to $\mathrm{REC}_{\text {SOLIDS }}$ ). Furthermore, the difference in $\mathrm{CY}_{\mathrm{CURD}}$ disappeared when the Holstein milk was modified to reach the fat:protein and TS contents seen in Jersey milk.

These between-breed differences may be due, at least in part, to differences in the population frequencies of genetic variations in milk proteins that are known to affect milk composition and coagulation properties (Bittante et al., 2012). For example, even after the data were corrected for milk composition, Walsh et al. (1998) found that milk with the B variant of $\kappa$-casein was associated with a significantly greater cheese yield than milk with the A variant.

\section{CONCLUSIONS}

In conclusion, we describe herein a model cheese-producing process that mimics all phases of cheese-making and show that it can be very useful for studying the variation among individual cows in terms of cheese yield and composition.

All of the analyzed yield and recovery traits varied substantially among individual cows and showed an almost normal distribution, with the exception of $\mathrm{REC}_{\mathrm{FAT}}$. Herd-test-date and DIM affected most of the analyzed traits. Parity effect was much less important, and the effect of the cheese-making vat was often not significant, confirming the good reproducibility of our technique. Comparisons among the analyzed traits indicated that (1) \% CY does not depend solely on the fat and protein (casein) contents of milk; (2) water trapped in curd has a higher variability than TS, and the former contributes significantly to explaining the individual variability of \%CY; (3) milk fat and protein recoveries in curd, and their losses in whey, are variable, affected by herd-test-date and individual causes of variation (parity, DIM); (4) TS and energy recoveries in curd, and their losses in whey, are variable and affected by herd-date and individual causes of variation; and (5) $\mathrm{dCY}$ of individual cows seem more affected by variation in MY than by variation in \% CY. The model cheese procedure described herein and the results obtained should facilitate our understanding of the variability and relationships among different cheese yield and recovery traits at the individual level, and ultimately of the economic value of milk. Furthermore, our findings 
underscore the need for further research on this topic, especially into the genetic backgrounds of these traits and methods for their indirect prediction.

\section{ACKNOWLEDGMENTS}

The authors thank the Autonomous Province of Trento (Italy) for funding the project, the project "Strengthening of the facilities supporting biotechnology research" of the Veneto Region (Italy) ("RISIB" SMUPR project 4145: Regional competitiveness and job creation; FESR 2007/2013 Action 1.1.1) for the availability of the instruments of the NIRS Food laboratory the Superbrown Consortium of Bolzano, and Trento (Trento, Italy) for support in sampling and recording activities; and Mauro Penasa, Nicola Cologna, and Ilario Bazzoli (all from DAFNAE; Department of Agronomy, Food, Natural resources, Animals and Environment, University of Padova, Italy) for their cooperation in sample collection, model cheese procedure setup, and initial analyses of data. The authors also thank the editor and reviewers for their useful comments.

\section{REFERENCES}

Aleandri, R., J. C. Schneider, and L. G. Buttazzoni. 1989. Evaluation of milk for cheese production based on milk characteristics and Formagraph measures. J. Dairy Sci. 72:1967-1975.

Ali, A. K. A., and G. E. Shook. 1980. An optimum transformation for somatic cell concentration in milk. J. Dairy Sci. 63:487-490.

ANARB (Associazione Nazionale Allevatori Razza Bruna Italiana). 2011. Herd book statistics. ANARB, Bussolengo, Italy.

Auldist, M. J., K. A. Johnston, N. J. White, W. P. Fitzsimons, and M. J. Boland. 2004. A comparison of the composition, coagulation characteristics and cheesemaking capacity of milk from Friesian and Jersey dairy cows. J. Dairy Res. 71:51-57.

Bachmann, H., Z. Kruijswijk, D. Molenaar, M. Kleerebezem, and J. E. T. van Hylckama Vlieg. 2009. A high-throughput cheese manufacturing model for effective cheese starter culture screening. J. Dairy Sci. 92:5868-5882.

Banks, J. M. 2007. Cheese yield. Pages 100-114 in Cheese Problems Solved. P. L. H. McSweeney, ed. Woodhead Publishing Ltd., Cambridge, UK.

Banks, J. M., W. Banks, D. D. Muir, and A. G. Wilson. 1981. Cheese yield: Composition does matter. Dairy Ind. Int. 46:15-22.

Banks, J. M., L. J. Clapperton, D. D. Muir, and A. K. Girdler. 1986. The influence of diet and breed of cow on the efficiency of conversion of milk constituents to curd in cheese manufacture. J. Sci. Food Agric. 37:461-468.

Banks, J. M., D. D. Muir, and A. Y. Tamine. 1984. Equations for estimation of the efficiency of Cheddar cheese production. Dairy Ind. Int. 49:14-17.

Bittante, G., A. Cecchinato, N. Cologna, M. Penasa, F. Tiezzi, and M. De Marchi. 2011a. Factors affecting the incidence of first-quality wheels of Trentingrana cheese. J. Dairy Sci. 94:3700-3707.

Bittante, G., C. Cipolat-Gotet, and A. Cecchinato. 2013. Genetic parameters of different measures of cheese-yield and milk nutrient recovery from an individual model cheese-manufacturing process. J. Dairy Sci. 96:7966-7979.

Bittante, G., N. Cologna, A. Cecchinato, M. De Marchi, M. Penasa, F. Tiezzi, I. Endrizzi, and F. Gasperi. 2011b. Monitoring of sensory attributes used in the quality payment system of Trentingrana cheese. J. Dairy Sci. 94:5699-5709.
Bittante, G., M. Penasa, and A. Cecchinato. 2012. Invited review: Genetics and modeling of milk coagulation properties. J. Dairy Sci. 95:6843-6870.

Bynum, D. G., and N. F. Olson. 1982. Influence of curd firmness at cutting on Cheddar cheese yield and recovery of milk constituents. J. Dairy Sci. 65:2281-2290.

Cecchinato, A., C. Cipolat-Gotet, J. Casellas, M. Penasa, A. Rossoni, and G. Bittante. 2013. Genetic analysis of rennet coagulation time, curd-firming rate, and curd firmness assessed on an extended testing period using mechanical and near-infrared instruments. J. Dairy Sci. 96:50-62.

Cecchinato, A., M. Penasa, M. De Marchi, L. Gallo, G. Bittante, and P. Carnier. 2011. Genetic parameters of coagulation properties, milk yield, quality, and acidity estimated using coagulating and noncoagulating milk information in Brown Swiss and HolsteinFriesian cows. J. Dairy Sci. 94:4214-4219.

Cipolat-Gotet, C., A. Cecchinato, M. De Marchi, M. Penasa, and G. Bittante. 2012. Comparison between mechanical and near-infrared optical methods for assessing milk coagulation properties. J. Dairy Sci. 95:6806-6819.

Cologna, N., R. Dal Zotto, M. Penasa, L. Gallo, and G. Bittante. 2009. A laboratory micro-manufacturing method for assessing individual cheese yield. Ital. J. Anim. Sci. 8(Suppl. 2):393-395.

De Marchi, M., G. Bittante, R. Dal Zotto, C. Dalvit, and M. Cassandro. 2008. Effect of Holstein Friesian and Brown Swiss breeds on quality of milk and cheese. J. Dairy Sci. 91:4092-4102.

Emmons, D. B., C. Dubé, and H. W. Modler. 2003. Transfer of protein from milk to cheese. J. Dairy Sci. 86:469-485.

Emmons, D. B., C. A. Ernstrom, C. Lacroix, and P. Verret. 1990 Predictive formulas for yield of cheese from composition of milk: A review. J. Dairy Sci. 73:1365-1394.

Emmons, D. B., and H. W. Modler. 2010. Invited review: A commentary on predictive cheese yield formulas. J. Dairy Sci. 93:55175537.

Everard, C. D., D. J. O'Callaghan, M. J. Mateo, M. Castillo, F. A. Payne, and C. P. O'Donnell. 2011. Effects of milk composition, stir-out time, and pressing duration on curd moisture and yield. J. Dairy Sci. 94:2673-2679.

Fagan, C. C., M. Castillo, F. A. Payne, C. P. O'Donnell, and D. J. O'Callaghan. 2007. Effect of cutting time, temperature, and calcium on curd moisture, whey fat losses, and curd yield by response surface methodology. J. Dairy Sci. 90:4499-4512.

Hallén, E., A. Lundén, T. Allmere, and A. Andrén. 2010. Casein retention in curd and loss of casein into whey at chymosin-induced coagulation of milk. J. Dairy Res. 77:71-76. http://dx.doi. org/10.1017/S0022029909990434.

Hicks, C. L., J. O'Leary, and B. E. Langlois. 1981. Equipment and procedure for manufacturing laboratory cheese curd. J. Dairy Sci. 64:523-525.

Hurtaud, C., J. L. Peyraud, G. Michel, D. Berthelot, and L. Delaby. 2009. Winter feeding systems and dairy cow breed have an impact on milk composition and flavour of two Protected Designation of Origin French cheeses. Animal 3:1327-1338.

Hurtaud, C., H. Rulquin, M. Delaite, and R. Vèritè. 1995. Apprèciation de l'aptitude fromagère des laits de vacches individuels. Tests d'aptitude fromagère et rendement fromager de fabrication. Ann. Zootech. 44:385-398.

Ikonen, T., O. Ruottinen, E.-L. Syväoja, K. Saarinen, E. Pahkala, and M. Ojala. 1999. Effect of milk coagulation properties of herd bulk milks on yield and composition of Emmental cheese. Agric. Food Sci. Finl. 8:411-422.

Jacob, M., D. Jaros, and H. Rohm. 2010. The effect of coagulant type on yield and sensory properties of semihard cheese from laboratory-, pilot- and commercial-scale productions. J. Dairy Technol. 63:370-380.

Janhøj, T., and K.B. Qvist 2010. The formation of cheese curd. Pages 130-165 in Technology of Cheesemaking. B. A. Law and A. Y. Tamine, ed. Wiley-Blackwell, Ames, IA.

Johnson, M. E., C. M. Chen, and J. J. Jaeggi. 2001. Effect of rennet coagulation time on composition, yield, and quality of reduced-fat Cheddar cheese. J. Dairy Sci. 84:1027-1033. 
Kefford, B., M. P. Christian, B. J. Sutherland, J. J. Mayes, and C. Grainger. 1995. Seasonal influences on Cheddar cheese manufacture: Influence of diet quality and stage of lactation. J. Dairy Res. 62:529-537.

Lucey, J., and J. Kelly. 1994. Cheese yield. J. Dairy Technol. 47:1-14.

Malacarne, M., A. Summer, E. Fossa, P. Formaggioni, P. Franceschi, M. Pecorari, and P. Mariani. 2006. Composition, coagulation properties and Parmigiano-Reggiano cheese yield of Italian Brown and Italian Friesian herd milks. J. Dairy Res. 73:171-177.

Martin, B., D. Pomies, P. Pradel, I. Verdier-Metz, and B. Remond. 2009. Yield and sensory properties of cheese made with milk from Holstein or Montbeliarde cows milked twice or once daily. J. Dairy Sci. 92:4730-4737.

Marziali, A. S., and K. F. Ng-Kwai-Hang. 1996. Relationships between milk protein polymorphisms and cheese yielding capacity. J. Dairy Sci. 69:1193-1201.

Melilli, C., J. M. Lynch, S. Carpino, D. M. Barbano, G. Licitra, and A. Cappa. 2002. An empirical method for prediction of cheese yield. J. Dairy Sci. 85:2699-2704.

Milesi, M. M., M. Candiaoti, and E. Hynes. 2007. Mini soft cheese as a simple model for biochemical studies on cheese-making and ripening. Lebenson. Wiss. Technol. 40:1427-1433.

Mistry, V. V., M. J. Brouk, K. M. Kasperson, and E. Martin. 2002. Cheddar cheese from milk of Holstein and Brown Swiss cows. Milchwissenschaft 57:19-23.

NRC. 2001 Nutrient Requirements of Dairy Cattle. 7th rev. ed. Natl. Acad. Press, Washington, DC.

Othmane, M. H., J. A. Carriedo, L. F. de la Fuente Crespo, and F. San Primitivo. 2002. An individual laboratory cheese-making method for selection in dairy ewes. Small Rumin. Res. 45:67-73.

Penasa, M., M. Cassandro, D. Pretto, M. De Marchi, A. Comin, S. Chessa, R. Dal Zotto, and G. Bittante. 2010. Short communication: Influence of composite casein genotypes on additive genetic variation of milk production traits and coagulation properties in Holstein-Friesian cows. J. Dairy Sci. 93:3346-3349.

Pereira, C. I., D. M. Neto, J. C. Capucho, M. S. Gião, A. M. P. Gomes, and F. X. Malcata. 2010. How three adventitious lactic acid bacteria affect proteolysis and organic acid production in model Portuguese cheeses manufactured from several milk sources and two alternative coagulants. J. Dairy Sci. 93:1335-1344.

Politis, I., and K. F. Ng-Kwai-Hang. 1988. Association between somatic cell count of milk and cheese-yielding capacity. J. Dairy Sci. $71: 1720-1727$.

Povinelli, M., C. Romani, L. Degano, M. Cassandro, R. Dal Zotto, and G. Bittante. 2003. Sources of variation and heritability estimates for milking speed in Italian Brown cows. Ital. J. Anim. Sci. 2(Suppl. 1):70-72.

Remeuf, F., V. Cossin, C. Dervin, J. Lenoir, and R. Tomassone. 1991. Relationships between physicochemical characteristics of milks and their cheese-making properties. Lait 71:397-421.
Samoré, A. B., F. Canavesi, A. Rossoni, and A. Bagnato. 2012. Genetics of casein content in Brown Swiss and Italian Holstein dairy cattle breeds. Ital. J. Anim. Sci. 11:e36.

Samoré, A. B., C. Romani, A. Rossoni, E. Frigo, O. Pedron, and A. Bagnato. 2007. Genetic parameters for casein and urea content in the Italian Brown Swiss dairy cattle. Ital. J. Anim. Sci. 6(Suppl.1):201-203.

Summer, A., P. Franceschi, A. Bollini, P. Formaggioni, F. Tosi, and P. Mariani. 2003. Seasonal variations of milk characteristics and cheesemaking losses in the manufacture of Parmigiano-Reggiano cheese. Vet. Res. Commun. 27(Suppl. 1):663-666.

Tiezzi, F., C. Maltecca, A. Cecchinato, M. Penasa, and G. Bittante. 2012. Genetic parameters for fertility of dairy heifers and cows at different parities, and relationships with production traits in first lactation. J. Dairy Sci. 95:7355-7362.

Tiezzi, F., C. Maltecca, M. Penasa, A. Cecchinato, Y. M. Chang, and G. Bittante. 2011. Genetic analysis of fertility in the Italian Brown Swiss population using different models and trait definitions. J. Dairy Sci. 94:6162-6172.

Van Slyke, L. L., and W. V. Price. 1952. Cheese. Orange-Judd Publ. Co., New York, NY.

Van Slyke, L. L., and C. A. Publow. 1910. The Science and Practice of Cheese Making. Orange Judd Company, New York, NY.

Verdier, I., J. B. Coulon, P. Pradel, and J. L. Berdaguè. 1995. Effect of forage type and cow breed on the characteristics of matured SaintNectaire cheeses. Lait 75:523-533.

Verdier-Metz, I., J. B. Coulon, and P. Pradel. 2001. Relationship between milk fat and protein contents and cheese yield. Anim. Res. 50:365-371.

Verdier-Metz, I., J. B. Coulon, P. Pradel, C. Viallon, and J. L. Berdaguè. 1998. Effect of forage conservation (hay or silage) and cow breed on the coagulation properties of milk and on the characteristics of ripened cheese. J. Dairy Res. 65:9-21.

Walsh, C. D., T. P. Guinee, W. D. Reville, D. Harrington, J. J. Murphy, B. T. O'Kennedy, and R. J. FitzGerald. 1998. Influence of $\kappa$-casein genetic variant on rennet gel microstructure, Cheddar cheesemaking properties and casein micelle size. Int. Dairy J. 8:707-714

Wedholm, A., L. B. Larsen, H. Lindmark-Mansson, A. H. Karlsson, and A. Andren. 2006. Effect of protein composition on the cheesemaking properties of milk from individual dairy cows. J. Dairy Sci. 89:3296-3305.

Zicarelli, L., A. Potena, M. Di Rubbio, A. Coletta, C. Caso, B. Gasparrini, and R. Di Palo. 2007. Estimation of buffalo cheese yield by using the chemical-physical parameters of the milk. Ital. J. Anim. Sci. 6(Suppl. 2):1100-1103. 